\title{
The Hippoboscidae (Insecta: Diptera) from Madagascar, With new records from the "Parc National de Midongy Befotaka"
}

\author{
RAHOLA N.*, GOODMAN S.M.** \& ROBERT V.*
}

\section{Summary:}

The Hippoboscidae or "louse-flies" is a family of pupiparous Diptera, which in their adult stage are ectoparasites of mammals and birds. This paper presents a comprehensive review of Malagasy Hippoboscidae. In total, amongst the 213 species of this family known worldwide, 14 have been reported in Madagascar, among which six are considered as endemic to the Malagasy region. In addition, data are presented from a collection of 17 Hippoboscidae obtained from seven species of forest-dwelling birds in the "Parc National de Midongy Befotaka", southeastern Madagascar, in 2003. The flies in this collection belong to three different species: Icosta malagasii (one), Ornithoica podicipis (ten) and Ornithoctona laticornis (six). The two former species were previously only known from single specimens in museum collections; the later species is distributed across much of the Afrotropical region and the records presented herein are the first for Madagascar. All the seven bird species are new hosts for hippoboscids. We present the first description of the male of Icosta malagasii. An illustrated dichotomous determination key of the 14 Malagasy species, based on morphological criteria only, is presented.

KEY WORDS: Hippoboscidae, birds, review, determination key, hostparasite relationship, taxonomy, Madagascar, Midongy Befotaka.
Résumé : LeS HIPPOBOSCIDAE (INSECTA: DIPTERA) DE MADAGASCAR, AVEC DE NOUVELlES OBSERVATIONS DANS LE PARC NATIONAL DE MidONGY BEFOTAKA

Les Hippoboscidae constituent une famille de Diptères pupipares dont le stade adulte est ectoparasite de mammifères et d'oiseaux. Nous présentons ici une revue de tous les Hippoboscidae connus de Madagascar. Parmi les 213 espèces de cette famille connues dans le monde, 14 ont été observées au moins une fois à Madagascar, parmi lesquelles six sont considérées comme endémiques de la région malgache. Nous présentons aussi la récolte de 17 Hippoboscidae adultes collectés de sept espèces d'oiseaux strictement forestiers en 2003 dans le Parc National de Midongy Befotaka, sud-est de Madagascar. Ces 17 hippobosques se répartissent en trois espèces : Icosta malagasii (un), Ornithoica podicipis (dix) et Ornithoctona laticornis (six). Les deux premières de ces espèces étaient précédemment connues par un unique spécimen enregistré dans les collections des muséums; 0. laticornis a une large répartition en zone Afrotropicale, mais il est trouvé pour la première fois à Madagascar. Chacune des sept espèces d'oiseaux constitue un nouvel hôte pour les hippobosques collectés. Nous proposons la première description du mâle d'Icosta malagasii. Nous présentons enfin une clé dichotomique illustrée, basée exclusivement sur des critères morphologiques, pour la détermination des 14 espèces malgaches.

MOTS-CLÉS: Hippoboscidae, oiseaux, revue, clé de détermination, relations hôte-parasite, taxonomie, Madagascar, Midongy Befotaka.

larval development takes place within the mother's abdomen and pupation occurs almost immediately after pre-pupae laying (Hutson, 1984). The Hippoboscidae belongs to the super-family of Hippoboscoidea, which groups four families of flies that are bloodsucking at the adult stage for both sexes. The four families consist of Hippoboscidae, the bat flies Nycteribiidae and Streblidae, and the tsetse flies Glossinidae. Hippoboscoidea are considered monophyletic, but based on current data, the basal relationships between the four families are not resolved (Dittmar et al., 2006). A recent checklist of Hippoboscidae across the world retains three subfamilies (Ornithomyinae, Hippoboscinae, and Lipopteninae), 21 genera, and 213 species (Dick, 2006). It has been shown that the two subfamilies Hippoboscinae and Lipopteninae are monophyletic groups (Petersen et al., 2007).

Caution must be taken with the name Hippoboscidae. In old taxonomic treatments, it was used to encompass the Hippoboscidae as defined today, as well as
* MIVEGEC (Maladies Infectieuses et Vecteurs : Écologie, Génétique, Évolution et Contrôle), IRD 224, CNRS 5290, Université Montpellier 1, Université Montpellier 2, Montpellier, France.

** Field Museum of Natural History, Chicago, Illinois, United States \& Vahatra, Antananarivo, Madagascar.

Correspondence: Vincent Robert, MIVEGEC, Centre IRD, 911, avenue Agropolis, BP 64501, 34394 Montpellier Cedex 5, France.

Tel.: 33 (0)467416127 - Fax: 33 (0)467 416330

E-mail: vincent.robert@ird.fr 
the bat-flies (Nycteribiidae and Streblidae). Irwin et al. (2003), following the BDWD (BioSystematic Database of World Diptera), used this old definition and indicated 760 valid species in the world and 15 in Madagascar, among which seven are Hippoboscidae sensu stricto.

Members of the Hippoboscidae are known to act as vectors of many infectious agents: protozoan, bacteria, helminthes, and perhaps viruses. They certainly transmit mammal Trypanosomatidae of the genus Megatrypanum (Baker, 1967; Oyieke \& Reid, 2003) and probably transmit avian trypanosomes (Kucera, 1983). Hippoboscidae are the only known vectors of Haemoproteus (an apicomplexan parasite of birds). Melophagus ovinus louse flies play a role in the transmission of Bartonella among ruminants (Halos et al., 2004; Reeves et al., 2006). In Kenya, the fly Hippobosca longipennis is thought to transmit to hyenas and domestic dogs the larva of the filarial nematoda Acanthocheilonema dracunculoides (Nelson, 1963). This filaria has been reported from domestic animals in Madagascar (Daynes, 1964). The louse fly Icosta americana is currently suspected in the transmission of West Nile Virus in North America (Farajollahi et al., 2005).

Although the importance of Hippoboscidae in the transmission of mammal and bird parasites in Madagascar has been suspected and to some extent documented (Daynes, 1964; Savage et al., 2009), members of this family remain poorly documented on the island. We here present the first comprehensive review of Malagasy Hippoboscidae (sensu stricto i.e. excluding Nycteribiidae and Streblidae). In addition, we propose the first illustrated dichotomous determination key for the genera and species currently known from Madagascar. Recent specimens of hippoboscids have been collected from Malagasy vertebrates and remain unstudied by fly specialists (e.g., Wright et al., 2009). Herein we present details on a hippoboscid collection obtained from forest-dwelling birds in the "Parc National de Midongy Befotaka", previously known as Midongy-Sud, southeastern Madagascar.

\section{REVIEW OF MALAGASY HIPPOBOSCIDAE BASED ON PUBLISHED LITERATURE}

工 1 nformation on Malagasy Hippoboscidae is rather limited and notably dispersed in the scientific literature. We found published records of 13 species recorded at least once on Madagascar. The host species (when known) and/or the context for Madagascar are presented in Table I. The numbers of species from the three subfamilies of Hippoboscidae - Ornithomyinae,
Hippoboscinae, and Lipopteninae - are 11, two, and zero, respectively. Six species of Ornithomyinae are presently considered as endemic to Madagascar. Individuals of eight species have been collected from a single individual host, including three different specific names proposed for the female flies (Icosta malagasii, Ornithomya sorbens, and Ornithoctona idonea), while the identity of the male remains unknown.

The genus Allobosca is composed by only one known species, $A$. crassipes. This species, considered endemic to Madagascar, has rudimentary wings and is known from several species of lemurs (Ferris \& Cole, 1922; Maa, 1969c). Proparabosca is a genus of Hippoboscidae, with only one known species, $P$. alata, which is an ectoparasite of the Indriidae Propithecus verreauxi in Namoroka National Park (Theodor \& Oldroyd, 1965). Most of the 171 species of Ornithomyinae are bird ectoparasites, with the exceptions of $A$. crassipes and $P$. alata (plus five species that parasite wallabies in Australia).

Icosta malagasii is only known by one female. It was collected as a "parasite sur l'aile d'un Coezach/ Sahafanjana/N: 115/R. M./ Inst. Sci. Madagascar" (Maa, 1969b). Sahafanjana is located in close proximity to the "Parc National de Mananara-Nord" and in the zone between Manambato and Anove (Quentin \& Villiers, 1973; Flint et al., 1987). One possibility in the identification of the "Coezach" is that it is a poor transliteration of the Malagasy vernacular name "Koa", which are members of the endemic genus Coua (subfamily Couinae). In certain Malagasy dialects, the last syllable of the vernacular name is accented and harshly pronounced. In the Parc Botanique et Zoologique de Tsimbazaza, Antananarivo (previously known as "Institut de Recherche Scientifique de Madagascar") there is a male specimen of C. caerulea, collected on 12 April 1955 by "R.M." at Sahafanjana. This information gives credence to the identity of the "Coezach" as a Cоиа.

Ornithoctona idonea is only known by one male and two females with two of these specimens, including the male holotype, being from Madagascar (Falcoz, 1929). Theses two Malagasy specimens formerly in the Falcoz collection are now untraceable. Curiously, although the male was designated as the holotype, it remains undescribed. Presently, the only available specimen is a pined female O. idonea (in the Muséum national d'Histoire naturelle, Paris), collected in "Africa" (no precise locality, no host record) and designed as a paratype by Falcoz (1929). Maa (1963) suppressed this species as a synonym of Ornithoctona laticornis, but subsequently (1969a) retained O. idonea as a dubious species waiting for the rediscovery of the holotype or the availability of new material from Madagascar. 


\begin{tabular}{|c|c|c|c|c|c|}
\hline Subfamily & Species & Hosts & Distribution & Main references & Context for Madagascar \\
\hline Ornithomyinae & $\begin{array}{c}\text { Allobosca crassipes } \\
\text { Speiser, } 1899\end{array}$ & $\begin{array}{l}\text { Mammals, } \\
\text { lemur } \\
\text { (Lemuridae } \\
\text { and Indriidae) }\end{array}$ & Madagascar & $\begin{array}{l}\text { Ferris \& Cole, 1922; } \\
\text { Maa, 1969c; } \\
\text { Vaughn \& McGee, } \\
2009\end{array}$ & $\begin{array}{l}\text { Known from seven lemur } \\
\text { species ex. Eulemur } \\
\text { macaco, E. rubriventer, } \\
\text { Lepilemur mustelinus, } \\
\text { Avabi laniger, Varecia } \\
\text { variegata variegata, } \\
\text { Propithecus diadema } \\
\text { and } P \text {. edwardsi }\end{array}$ \\
\hline
\end{tabular}

\begin{tabular}{|c|c|c|c|}
\hline $\begin{array}{l}\text { Proparabosca alata } \\
\text { Theodor \& Oldroyd, } 1965\end{array}$ & $\begin{array}{l}\text { Mammals, } \\
\text { lemurs } \\
\text { (Indriidae) }\end{array}$ & Madagascar & $\begin{array}{c}\text { Theodor \& Oldroyd, } \\
1965\end{array}$ \\
\hline
\end{tabular}

One record $(1 \hat{\delta}+1$ q);

known from one lemur species ex Propithecus verreauxi coronatus from Namoroka

\begin{tabular}{ccccc}
\hline $\begin{array}{c}\text { Icosta ardeae ardeae } \\
\text { (Macquart, 1835) }\end{array}$ & $\begin{array}{c}\text { Birds, } \\
\text { Ardeidae }\end{array}$ & $\begin{array}{c}\text { Cosmopolitan } \\
\text { except Americas }\end{array}$ & Maa, 1969b & Similar to continental Africa \\
\hline $\begin{array}{c}\text { Icosta minor } \\
\text { (Bigot, 1858) }\end{array}$ & $\begin{array}{c}\text { Birds, } \\
\text { Passeriformes } \\
\text { and Cuculidae }\end{array}$ & $\begin{array}{c}\text { Africa, } \\
\text { Massin }\end{array}$ & Maa, 1964 & $\begin{array}{c}\text { One record (1 +) } \\
\text { ex Centropus toulou } \\
\text { from Marovoay }\end{array}$ \\
\hline
\end{tabular}

\begin{tabular}{cccc}
\hline $\begin{array}{c}\text { Icosta malagasii } \\
\text { Maa, } 1969\end{array}$ & $\begin{array}{c}\text { Unknown birds, } \\
\text { probably } \\
\text { Falconiformes }\end{array}$ & $\begin{array}{c}\text { Madagascar, } \\
\text { perhaps } \\
\text { Grande Comore }\end{array}$ & $\begin{array}{c}\text { Maa, 1969b } \\
\text { One single female "parasite } \\
\text { sur l'aile d'un Coezach" } \\
\text { (see text) from Sahafanjana } \\
\hat{\delta} \text { previously unknown }\end{array}$ \\
\hline
\end{tabular}

Ornithoctona idonea Birds, Madagascar $\quad$ Falcoz, 1929; $\quad$ One record $(10+2$ +2$)$

Falcoz, 1929 Leptosomatidae Maa, 1969a ex Leptosomus discolor, no
precise locality, no material available, ô not described

\begin{tabular}{|c|c|c|c|c|}
\hline $\begin{array}{l}\text { Ornithoctona plicata } \\
\text { von Olfers, } 1816\end{array}$ & $\begin{array}{c}\text { Birds } \\
\text { (12 orders of birds) }\end{array}$ & $\begin{array}{c}\text { Cosmopolitan } \\
\text { except } \\
\text { Americas }\end{array}$ & Мaа, 1969c & Similar to continental Africe \\
\hline
\end{tabular}

\begin{tabular}{|c|c|c|c|c|}
\hline $\begin{array}{l}\text { Ornithoica podicipis } \\
\text { von Röder, } 1892\end{array}$ & $\begin{array}{l}\text { Birds, } \\
\text { Ardeidae }\end{array}$ & Africa & $\begin{array}{l}\text { Bequaert, 1954; } \\
\text { Maa, } 1966\end{array}$ & $\begin{array}{l}\text { One uncertain record ex } \\
\text { Bubulcus ibis, no precise } \\
\text { locality, no precise sex }\end{array}$ \\
\hline $\begin{array}{c}\text { Ornithoica hovana } \\
\text { Maa, } 1966\end{array}$ & $\begin{array}{c}\text { Birds, } \\
\text { Threskiornithidae }\end{array}$ & Madagascar & Maa, 1966 & $\begin{array}{c}\text { One record (1 } \hat{0}, 3 \text { \&) ex } \\
\text { Lophotibis cristata, } \\
\text { from Tanosy, Tolagnaro }\end{array}$ \\
\hline $\begin{array}{l}\text { Ornithomya sorbens } \\
\text { Hutson, } 1971\end{array}$ & $\begin{array}{c}\text { Birds, } \\
\text { Hirundinidae }\end{array}$ & Madagascar & Hutson, 1971 & $\begin{array}{l}\text { One record }(1 \text { } 9) \text { ex } \\
\text { unknown swallow species, } \\
\text { from "km } 50 \text { route } \\
\text { Majunga", o unknown }\end{array}$ \\
\hline $\begin{array}{c}\text { Pseudolynchia canariensis } \\
\text { (Macquart, 1840) }\end{array}$ & $\begin{array}{c}\text { Wild birds } \\
\text { and domestic pigeons }\end{array}$ & Cosmopolitan & Maa, 1962 & $\begin{array}{c}\text { One record }\left(\begin{array}{l}1 \\
\delta\end{array}\right) \text { from } \\
\text { Maroantsetra, Tamatave, } \\
\text { host not indicated, } \\
\text { probably domestic pigeon }\end{array}$ \\
\hline
\end{tabular}

\begin{tabular}{|c|c|c|c|c|c|}
\hline \multirow[t]{2}{*}{ Hippoboscinae } & $\begin{array}{c}\text { Hippobosca variegata } \\
\text { Megerle, } 1803\end{array}$ & $\begin{array}{c}\text { Big domestic } \\
\text { mammals, horses } \\
\text { and cattle }\end{array}$ & $\begin{array}{l}\text { Sub-Saharan } \\
\text { Africa } \\
\text { and Asia }\end{array}$ & Maa, 1962 & $\begin{array}{c}\text { A lot of records, } \\
\text { localities and vertebrate } \\
\text { hosts are indicated }\end{array}$ \\
\hline & $\begin{array}{c}\text { Hippobosca longipennis } \\
\text { Fabricius, } 1805\end{array}$ & $\begin{array}{c}\text { Mammals, } \\
\text { Carnivora } \\
\text { (Canidae, Hyaenidae, } \\
\text { Viveridae, Felidae) }\end{array}$ & $\begin{array}{l}\text { Africa, } \\
\text { Europe, } \\
\text { Asia }\end{array}$ & Maa, 1969c & $\begin{array}{c}\text { A lot of records, } \\
\text { localities and vertebrate } \\
\text { hosts are indicated }\end{array}$ \\
\hline
\end{tabular}

Table I. - Hippoboscidae recorded at least once on Madagascar based on information from the literature. 
Pseudolynchia canariensis, the pigeon louse fly, is found in most parts of the tropical and sub-tropical areas of the world and associated with domestic pigeons and doves. Pseudolynchia canariensis is the vector for the Apicomplexa protozoan Haemoproteus columbae, a parasite that can be fatal to young pigeons.

Hippobosca variegata, a species distributed in subSaharan Africa and Asia, has also been observed in the Comoros Archipelago, specifically on Grande Comore and Mayotte (Brunhes, 1978). The natural host of this fly is unknown (Maa, 1969c). This species is common on Malagasy cattle (Maa, 1962). Hippobosca longipennis is known from introduced carnivorans on Madagascar (Bequaert, 1939).

On the Aldabra Atoll, Seychelles, which is $420 \mathrm{~km} \mathrm{NW}$ of Madagascar, Cogan et al. (1971) reported that local land birds were rarely and only lightly parasitized with one unspecified species of Hippoboscidae. In contrast, bird species occurring in marine environments had notably higher concentrations of parasites, particularly far-ranging groups like the boobies and tropicbirds heavily parasitized by Olfersia aenescens and frigates by Olfersia spinifera.

\section{ORIGINAL OBSERVATIONS ON HIPPOBOSCIDAE FROM THE "PARC NATIONAL DE MIDONGY BEFOTAKA"}

\section{STUDY AREA}

1 he "Parc National de Midongy Befotka" is located in the southeastern portion of Madagascar and along the western flank of a chain of northsouth oriented mountains running the length of much of eastern Madagascar. All of the sites visited were in undisturbed or largely undisturbed natural forest classified as "Humid Forest" (Moat \& Smith, 2007). Meteorological patterns in the village of Midongy-Sud, in close proximity to the park, include an average of $1,825 \mathrm{~mm}$ of rain per year, falling on 170 days, with the wettest month being January, and the annual mean temperature of $18^{\circ} \mathrm{C}$ (Donque, 1975). Hence, the zone does not have a pronounced dry season.

\section{BIOLOGICAL MATERIAL}

During field expeditions, ornithologists mist-netted birds in the "Parc National de Midongy Befotaka". Four-panelled mist-nets measuring $12 \times 2.4 \mathrm{~m}$ with $36 \mathrm{~mm}$ mesh were installed at ground level in the forest understory. After being dispatched, certain birds retained as voucher specimens and for other research purposes, were individually placed in clean plastic bags with a small cotton ball moisten with ethyl acetate. All ectoparasites recovered were preserved in ETOH and are held in the collections of the Field Museum of Natural History, Chicago.

All the Hippoboscidae reported on herein were collected from birds captured between 27 October and 14 November 2003; other details on the hosts are presented in Table II.

The determination of these Hippoboscidae flies used Maa's (1963) key at the levels of subfamily and genus. The species determination was subsequently inferred using other references (Maa, 1966 for Ornithoica; Maa, 1969a for Ornithoctona; and Maa, 1969b for Icosta). Following Maa (1969b), O. idonea "would be separable from $O$. laticornis in having antennal appendage relatively more acute at apex, palpus longer, mesosternal processes closer to each other and posterior marginal bristles on laterite two much shorter."

\section{RESULTS}

In total, 17 Hippoboscidae specimens were collected from 11 individual birds belonging to seven different bird species (Table II). They belong to three species of Ornithomyinae, namely Icosta malagasii, Ornithoica podicipis, and Ornithoctona laticornis. The two former species were previously only known from single museum specimens and are here represented in the Midongy Befotaka collection by an additional one and ten individuals, respectively. Further, based on this material, the male of I. malagasii can now be described (see below) and for the first time O. laticornis is documented on Madagascar.

New records include collection of I. malagasii had been collected from Accipiter francesii; Ornithoica podicipis from Atelornis pittoides, Accipiter francesii, Otus rutilus, Brachypteracias leptosomus, and Streptopelia picturata; and O. laticornis from Atelornis crossleyi, Atelornis pittoides, and Monticola sharpei.

\section{DISCUSSION}

The specimens recorded from the "Parc National de Midongy Befotaka" are the first reported in detail from wild Malagasy forest-dwelling birds. Within this material, we identified specimens (five females and one male) as O. laticornis because they perfectly match Maa's description (1969a). However, it is hard to definitely exclude O. idonea because of Falcoz's imprecise drawings and description. Within these six specimens, there is notable polymorphism in antenna shape, setae of the first sternite, and ocellus area. Individuals of both sexes of O. laticornis in Madagascar support Maa's (1963) suggestion that O. idonea is a synonym of $O$. laticornis. We present the second record of $O$. podicipis on Madagascar (following the first record 


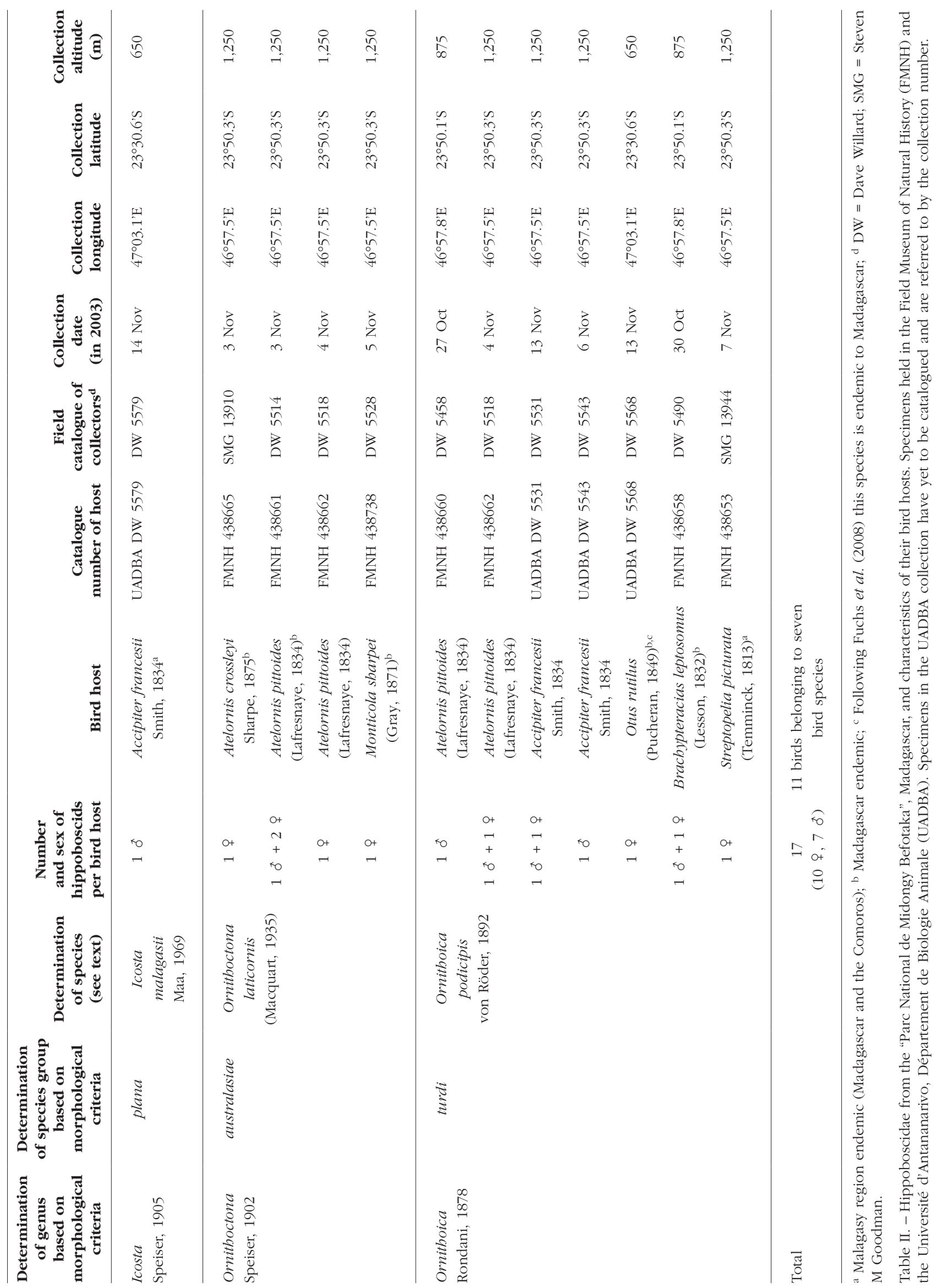


used in the original description), with the identification of five new host birds for this hippoboscid. Given the high level of endemicity of Malagasy birds at different taxonomic levels, including $51 \%$ of the 209 nesting bird species (Goodman \& Hawkins, 2008), it is rather striking that there has not been a greater radiation of hippoboscid species, as is known in other groups of blood-sucking flies parasites of vertebrates (e.g. Dick, 2007). Perhaps current low-levels of measured species diversity within Malagasy hippoboscids are in part associated with few field collections of these flies. Another explanation is that within the species groups with broad extralimital distributions, such as different genera within the Ornithomyinae, unrecognized cryptic species occur on Madagascar. Molecular genetic studies of recent collections of hippoboscids from Madagascar and neighbouring islands should help resolve these questions.

\section{DESCRIPTION OF THE MALE OF ICOSTA (ICOSTA) MALAGASII MAA, 1969}

The male is very similar to the female, as described by Maa (1969b), but differs as follows. Abdomen with three tergal plates, the first one is dark, narrow, lining a.

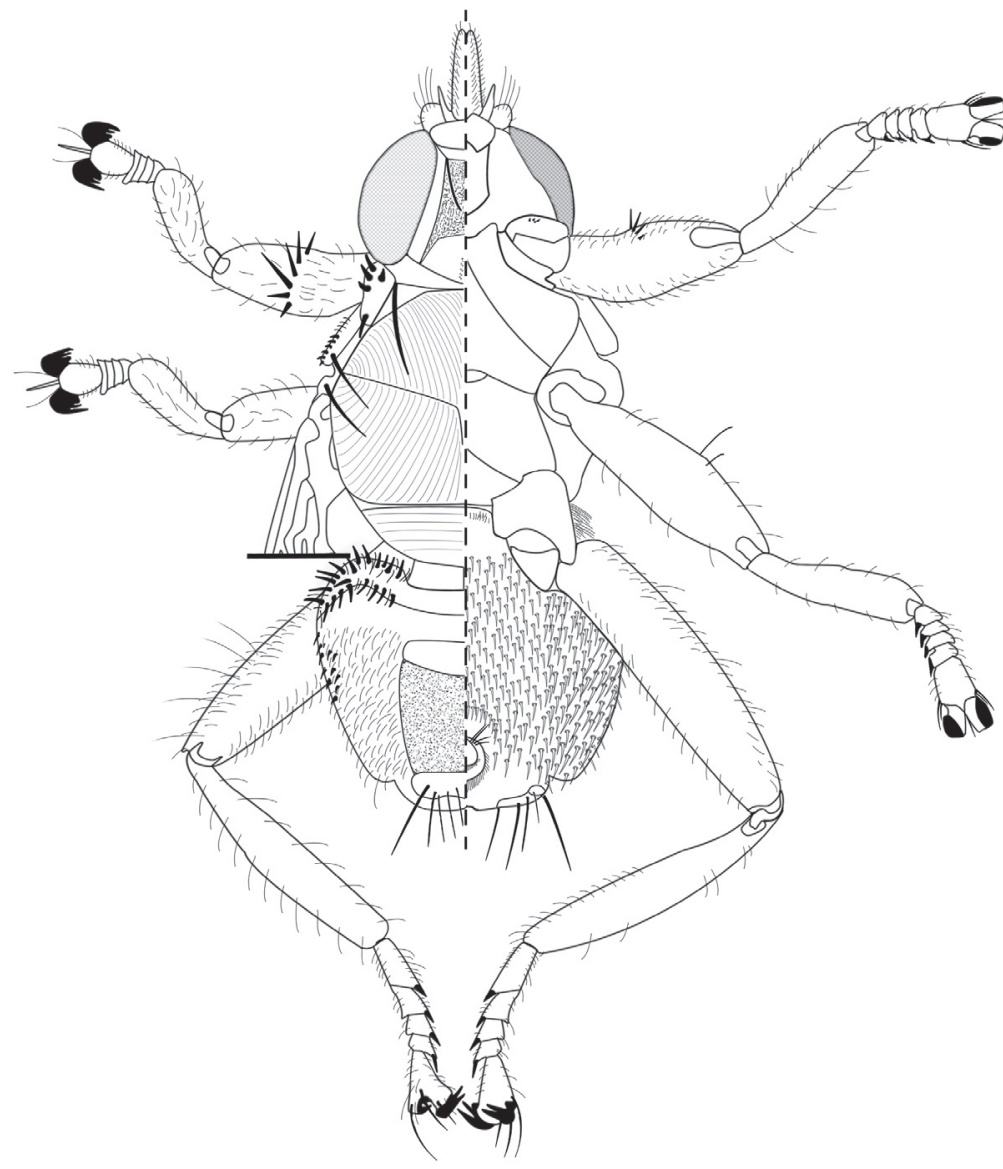

b.

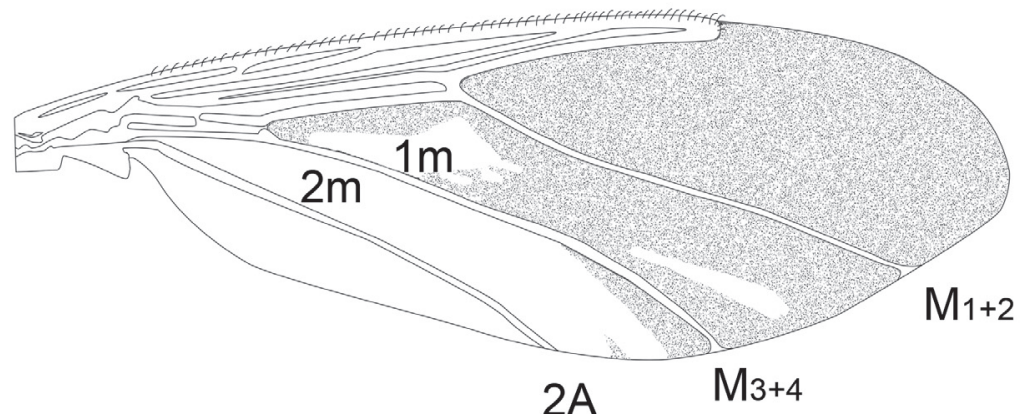

Plate 1. - a. Icosta (Icosta) malagasii, o in dorsal (left) and ventral (right) view; b. Icosta (Icosta) malagasii, ô wing. 
the abdomen basally, and extending antero-laterally. The second tergal plate is linked to the third one by a broad striate zone bearing small and narrow setae. The third tergal plate (tergite VI) bears five to seven pairs of long dark bristles projecting posteriorly. Ventrally the urogenital area is surrounded by small and narrow setae and anteriorly by a spot of dark bristles. The antenna is notably less hirsute than in the female (Plate 1, Figs a, b).

\section{DICHOTOMIC KEY FOR DETERMINATION OF MALAGASY HIPPOBOSCIDAE}

- Key to Genera of Hippoboscidae

1- Wing abnormal in size, frons longer than wide, hind femur almost as long as thick and fore tarsus with spatulate setae (Plate 2, Fig. e) .................. Allobosca (with one species of this genus recorded in Madagascar: A. crassipes Speiser, 1899)

- Wing fully developed and functional 2

2- Wing (Plate 3, Fig. d) with 2 or 1 crossveins ( $r-m$, im)

- Wing with 3 crossveins ( $r$ - $m$, im, mcu). Ocelli present

3- Wing with only $r-m$ crossvein present

Pseudolynchia (with one species of this genus recorded in Madagascar: P. canariensis (Maquart, 1840))

- Wing with two crossveins 4

4- Wing with 2 delineated crossveins, wing membrane of all open cells distinctly wrinkled. Pronotum large and forming an observable neck-like segment between head and mesonotum. Ocelli always absent ..... Hippobosca

- Crossvein $i m$ with a transparent whitish spot (Plate 4, Fig. a) Icosta

5- Tarsal claws simple but seemingly bifid (because of the presence of a basal lobe which may be mistaken as basal denticle of claw) (Plate 3, Fig. f) ............. 6

- Tarsal claws bidentate but seemingly trifid (Plate 3, Fig. g)

6- Wing densely ciliate along apical and anal margins and setulose at apical area. Vertical bristles each arising from nipple-like tubercle (Plate 3, Fig. a). Humeral callus (Plate 3, Fig. e) hardly protruding laterocephalad. Male hind trochanter with spine-like setae

Ornithoica

- Humeral callus weak, rounded not prominent with short setae at apex and 3 longer setae. Scutellum rhom- boid without long setae. Wing with seven longitudinal veins. Anal cell strongly sclerotised and triangular. $M_{1+2}, M_{3+4}$ and anal vein ending a short distance before wing margin (Plate 2, Fig. d). Long pregenital plates on female abdomen (Plate 2, Fig. a) ...... Proparabosca (with one species of this genus recorded in Madagascar: P. alata Theodor \& Oldroyd, 1965)

7- Wing with vein $2 A$ hardly visible and lower calypter exceptionally large. Antenna large, broad, leaf-shaped or spoon-shaped with distinct outer dorsal rim. Humeral callus very strong

Ornitboctona

- Antenna small, narrow, never leaf- or spoon-like. Abdomen always with median tergal plates. Axillary cord fringed with pale soft hair ............. Ornithomya (with one species of this genus recorded in Madagascar: O. sorbens Hutson, 1971; Plate 5, Figs g, h)

- Key to species of the genus Hippobosca Linnaeus, 1758

1- Apical abscissa of vein $R_{4+5}, 4$ to 5 times as long as full length of $R_{2+3}$. Abdomen lacking median tergal plates.

Hippobosca variegata Megerle, 1803

- Apical abscissa of vein $R_{4+5}$ not longer than full length of $R_{2+3}$. Abdomen with 3 median tergal plates. Prosternum hardly shorter than wide, scutellum usually almost entirely pale.

Hippobosca longipennis Fabricius, 1805

- Key to species of the genus Icosta Speiser, 1905

1- Venter of femur III densely uniformly setose except an oval bare area at base. Male lacking tergite 3 . Female with setae on median area of abdominal venter distinctly paler, longer and finer than those on submedian area which are more or less spine-like and similar to ventral setae near laterite 3 (Plate 4, Figs a, b, c).

Icosta (Ardmoeca) ardeae ardeae (Macquart, 1835)

- Venter of all femora bare besides few marginal setae 2

2- Tarsomeres 3 and 4 of foreleg clearly asymmetrical, with posterior apical lobes markedly longer than corresponding anterior ones (Plate 3, Fig. c); female urogenital area anteriorly fenced by pair of small setal patches. Wing setulae confined to cell $1 \mathrm{~m}$ et $2 \mathrm{~m}$, cell $1 m$ fully covered except a basal bare spot very close to $M_{3+4}$; cell $2 m$ almost entirely bare except at apex where setulae projecting anterally in a sharp process (Plate 4, Figs d, e, f, g, h).

Icosta (Icosta) malagasii Maa, 1969

- Tarsus 1 not apically asymmetrical. Lateral fence of $q$ urogenital area composed of $5 \pm$ robust setae which 
a.

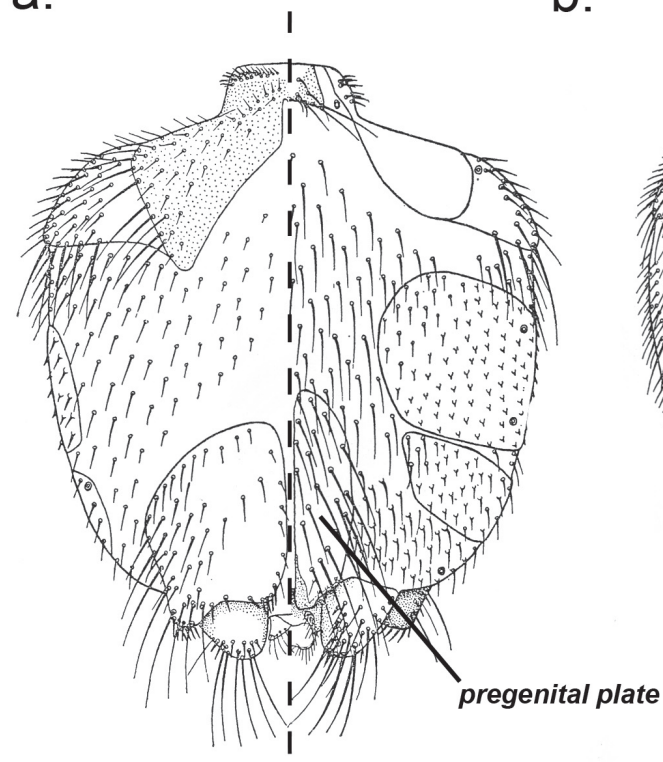

西

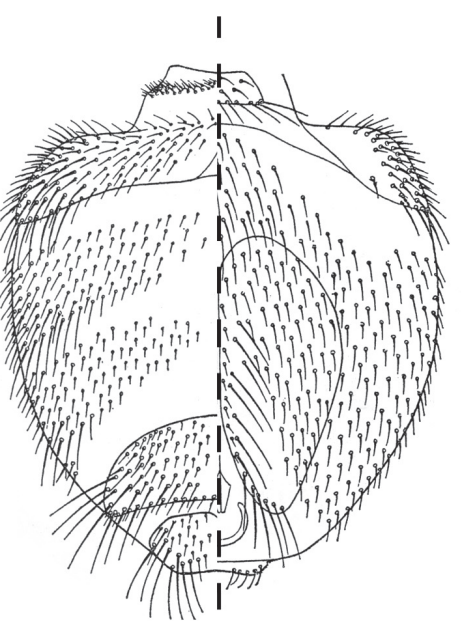

C.

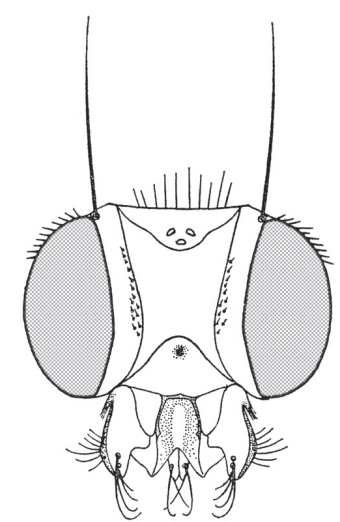

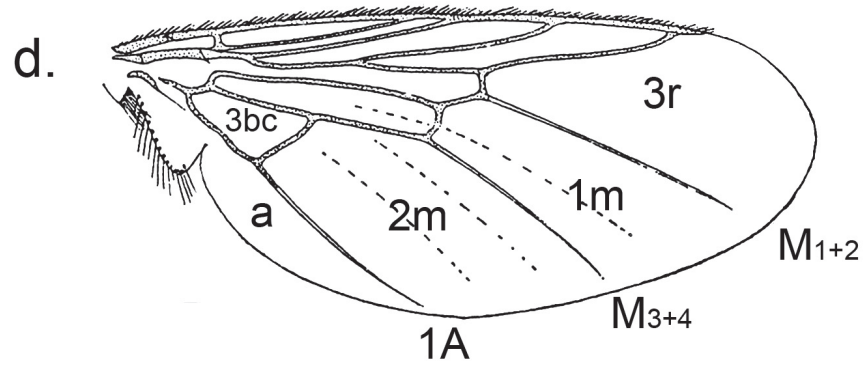

e.

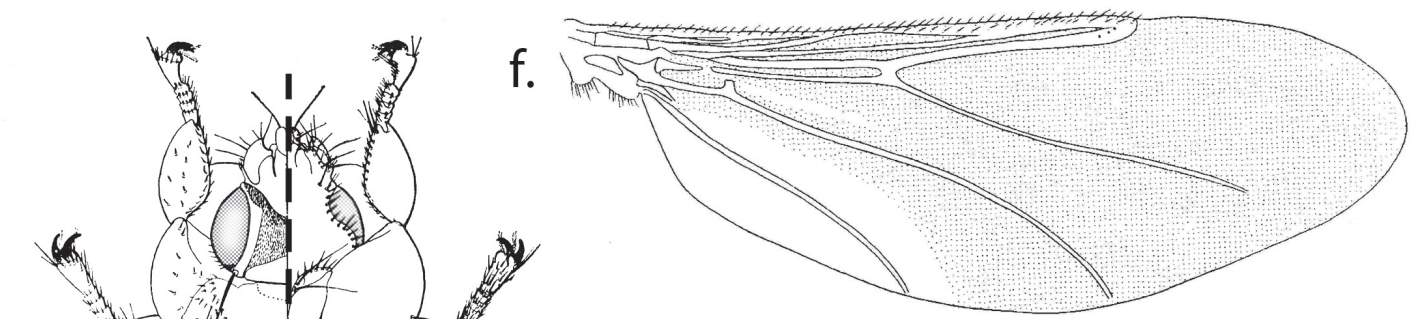

g.

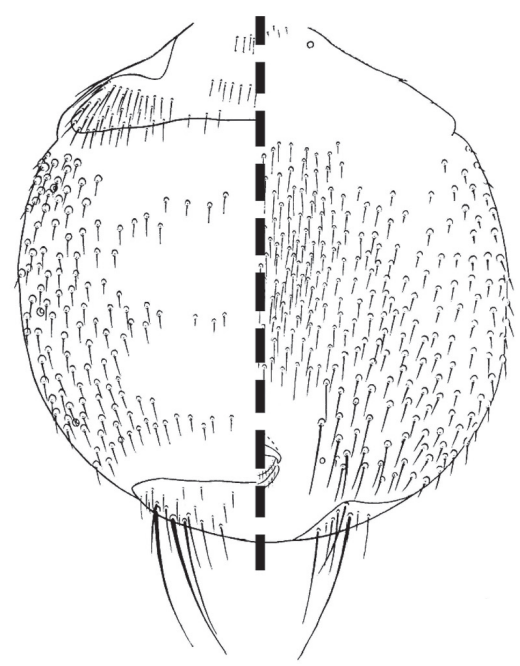

Plate 2. - a. Proparabosca alata, + abdomen in dorsal (left) and ventral (right) view; b. Proparabosca alata, ô abdomen in dorsal (left) and ventral (right) view; c. Proparabosca alata, head in dorsal view; d. Proparabosca alata, wing; e. Allobosca crassipes, $ᄋ$ in dorsal (left) and ventral (right) view; f. Icosta (Ornithoponus) minor, $q$ wing; g. Icosta (Ornithoponus) minor, $q$ abdomen in dorsal (left) and ventral (right) view. 


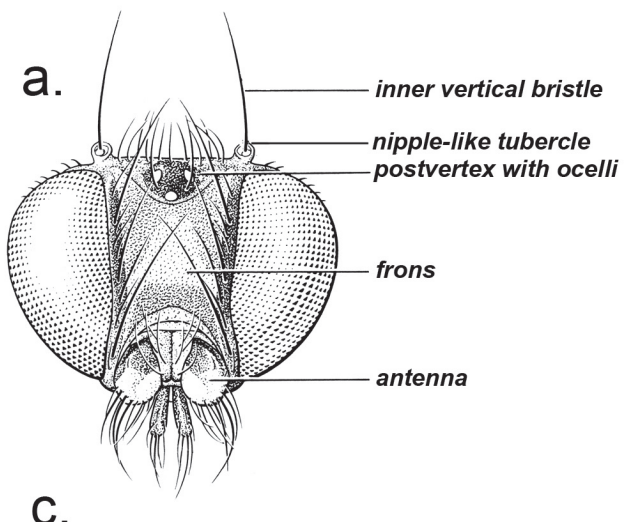

b.

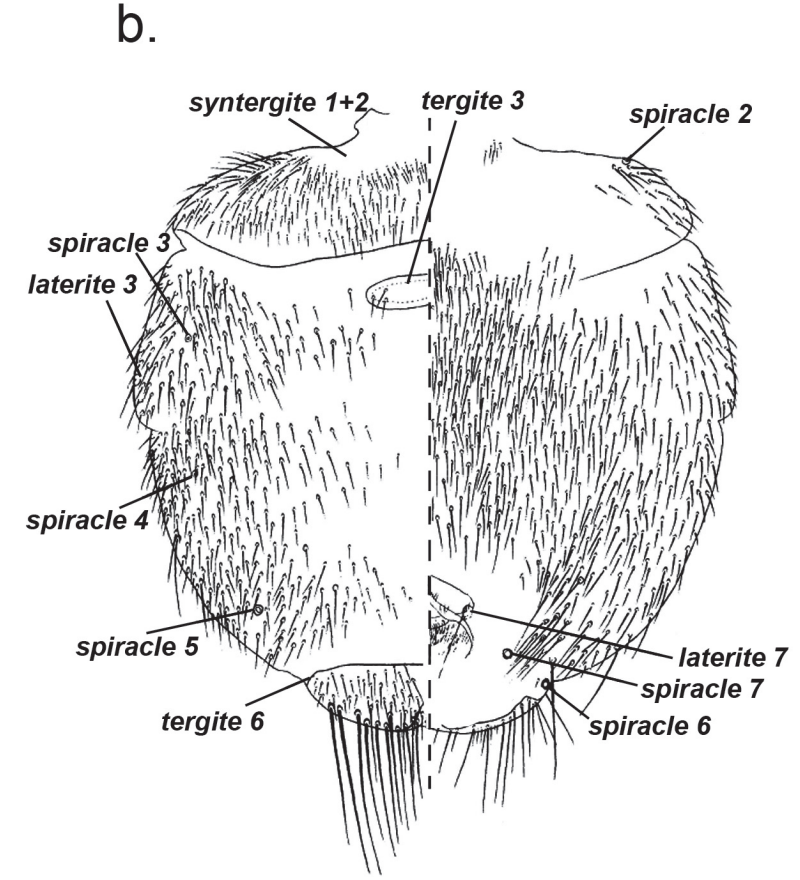

d.
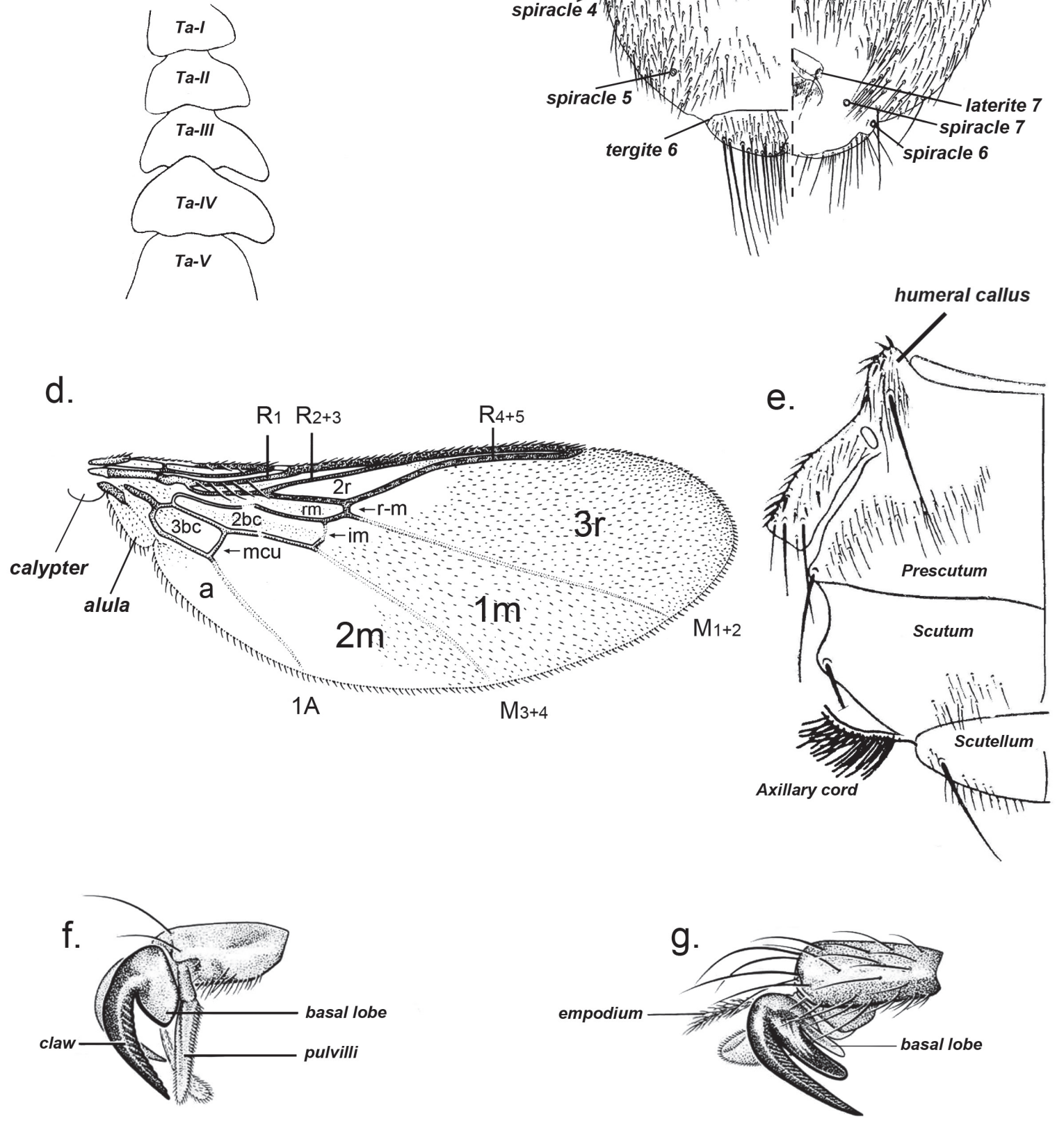

Plate 3. - a. Ornithoica sp. head; b. Icosta sp. abdomen showing plates and spiracles in dorsal (left) and ventral (right) view; c. Icosta sp. tarsus I with the fives tarsomeres (Ta-III and Ta-IV are asymmetrical); d. Ornithoica sp. wing showing venation and cells (3bc, anal cell; a, axillary lobe; A, anal vein; R, radial; M, media; $\mathrm{r}-\mathrm{m}$, discal; im, postical; mcu, base of upper postical); e. Icosta sp. thorax in dorsal (left) view; f. tarsal claw simple; g. tarsal claw bidentate. 
a.

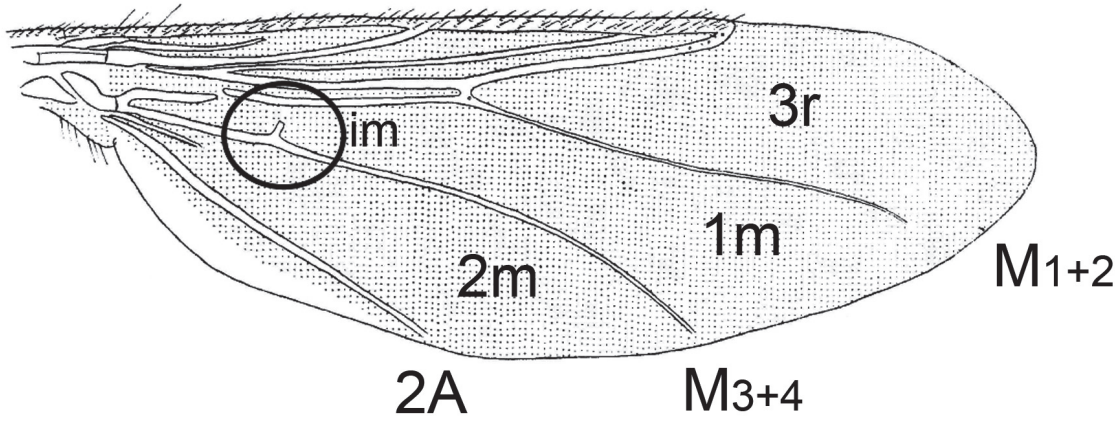

b.
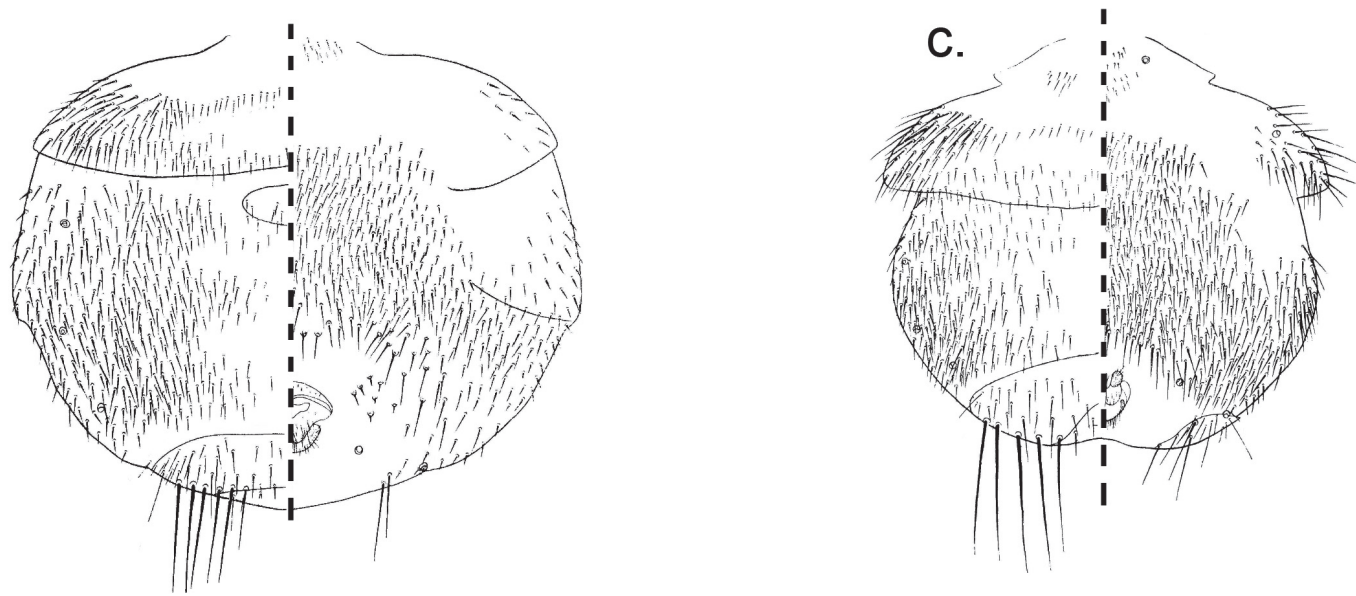

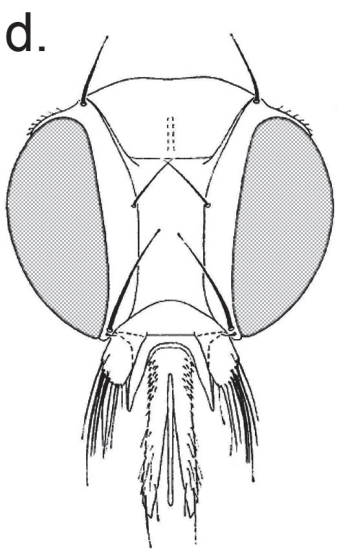

g.

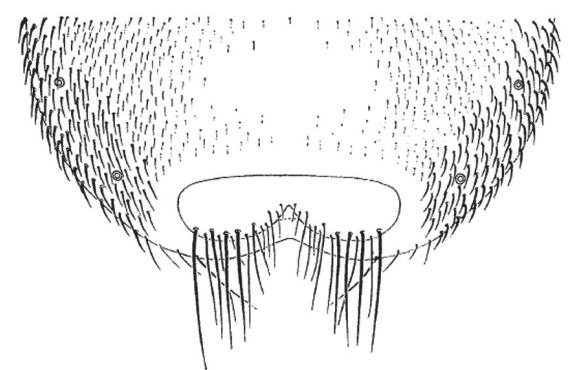

e.

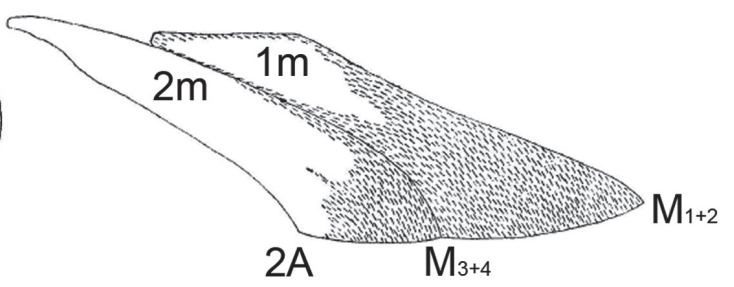

$\mathrm{M}_{1+2}$

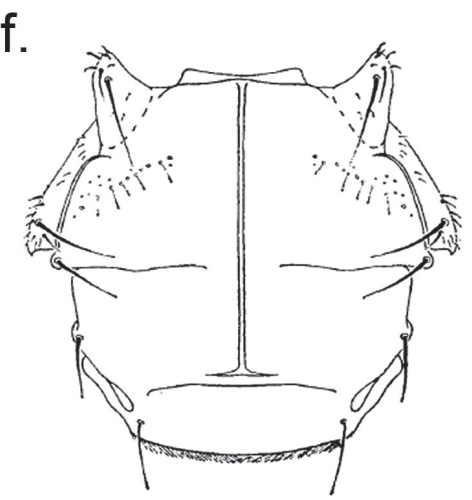

h.

Plate 4. - a. Icosta (Ardmoeca) ardeae ardeae, wing (A, anal vein; R, radial; M, media; im, postical); b. Icosta (Ardmoeca) ardeae ardeae, 9 abdomen in dorsal (left) and ventral (right) view; c. Icosta (Ardmoeca) ardeae ardeae, ô abdomen in dorsal (left) and ventral (right) view; d. Icosta (Icosta) malagasii, $q$ head in front view; e. Icosta (Icosta) malagasii, $q$ wing (media cells only) with setulae distribution; f. Icosta (Icosta) malagasii, o thorax in dorsal view; g. Icosta (Icosta) malagasii, $q$ abdominal apex in dorsal view; h. Icosta (Icosta) malagasii, + abdominal apex in ventral view. 
a.

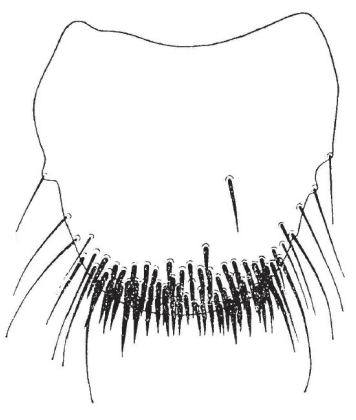

b.

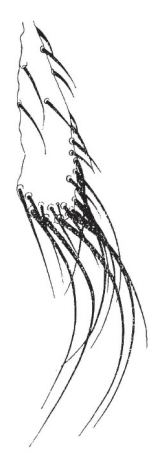

c.

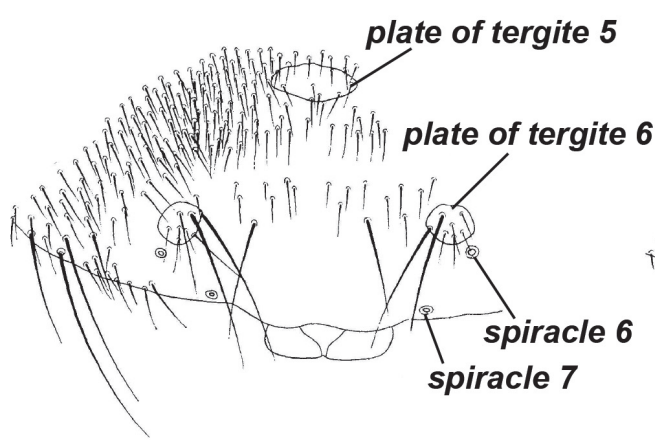

d.

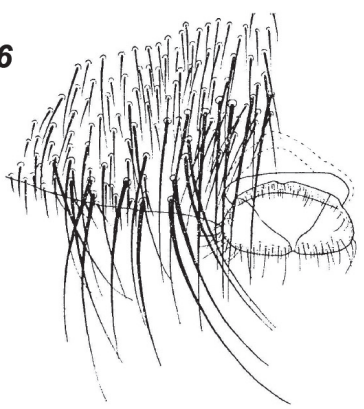

e.

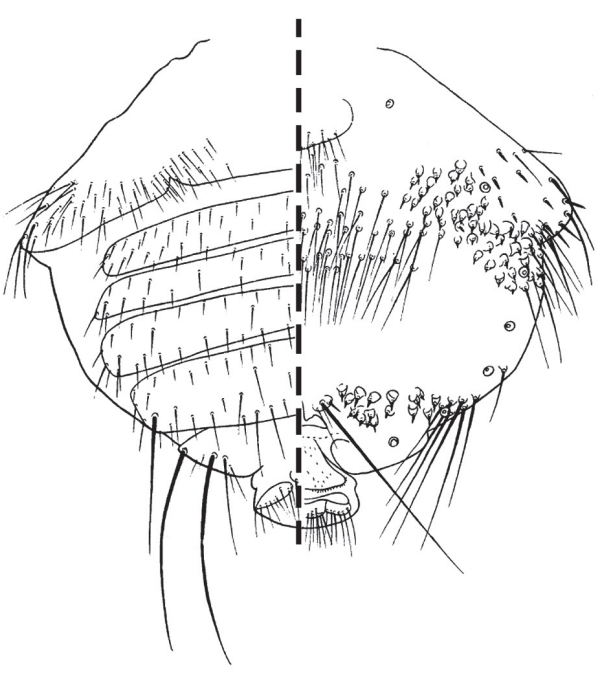

f.

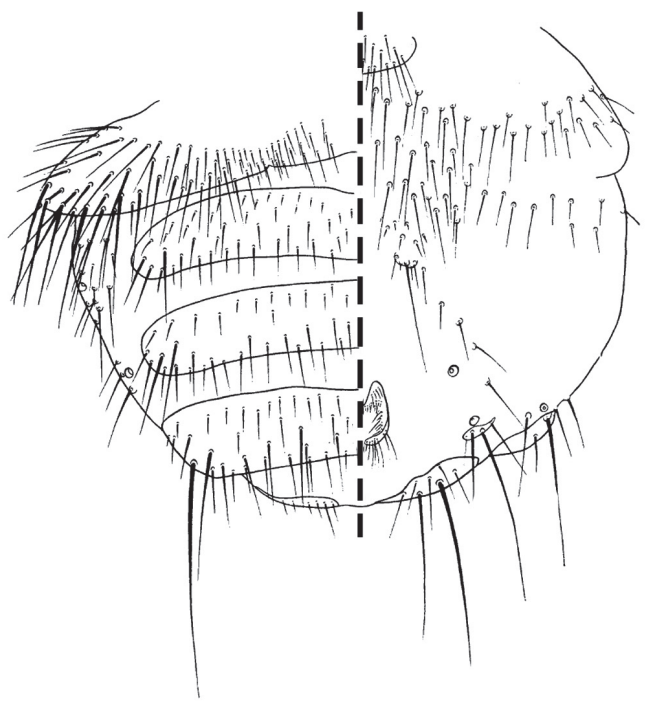

g.

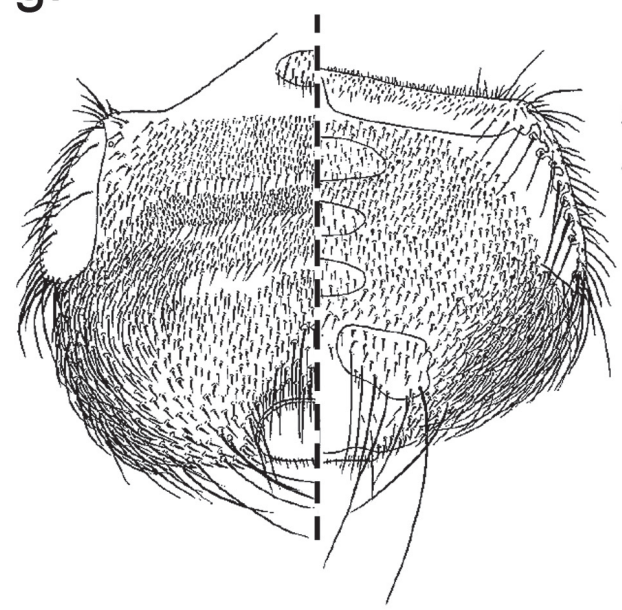

h.

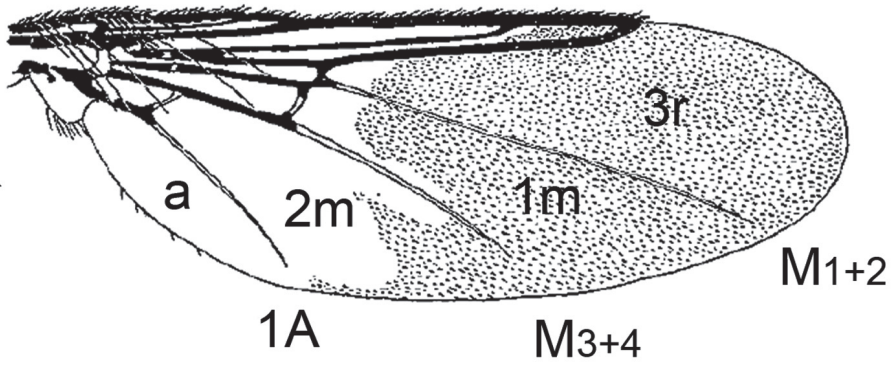

Plate 5. - a. Ornithoctona laticornis, $q$ basal abdominal tergite; b. Ornithoctona laticornis, $q$ antero-lateral area of abdomen; c. Ornithoctona laticornis, $q$ abdominal apex in dorsal view; d. Ornithoctona laticornis, $q$ abdominal apex in ventral view; e. Ornithoica (Ornithoica) hovana, $q$ abdomen in dorsal (left) and ventral (right) view; f. Ornithoica (Ornithoica) hovana, ơ abdomen in dorsal (left) and ventral (right) view; g. Ornithomya sorbens, + abdomen in dorsal (left) and ventral (right) view; h. Ornithomya sorbens, $q$ wing (a, anal cell; A, anal vein; r, radial; m, media). 
a.

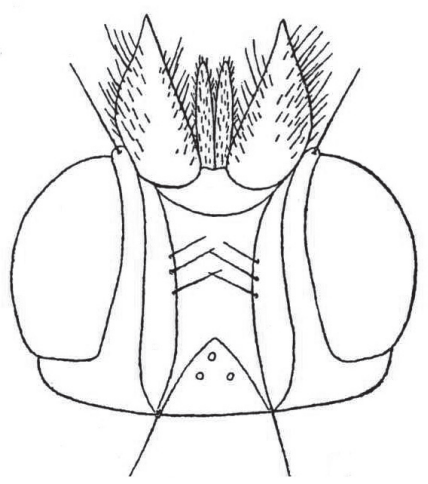

b.

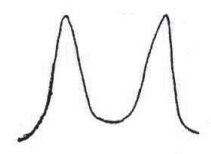

C.

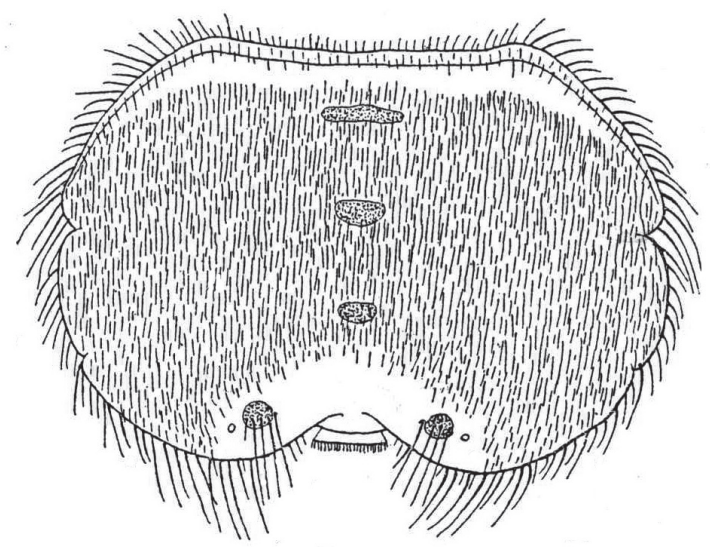

Plate 6. - (from Falcoz's 1929 drawings). a. Ornithoctona idonea, + head; b. Ornithoctona idonea, $q$ mesosternal process; c. Ornithoctona idonea, + abdomen in dorsal view.

are hardly longer than width of infra anal plate. Setae around $\delta$ abdominal spiracles 3-5 almost uniformly fine. Mesosternal process hardly visible. Metabasisternum never produced into posterolateral process (Plate 2, Figs f, g).

Icosta (Ornithoponus) minor Bigot, 1858

- Key to species of the genus Ornithoctona Speiser, 1902

1- Wing membrane entirely bare, at most with a very narrow setulose line on costal margin near apex; anterior mesosternal process distinctly shorter than interdistance of their apices; posterior ocelli hardly farther from each other than from anterior ocellus. Female abdomen lacking median tergal plates. Wing not less than $7 \mathrm{~mm}$ long.

Ornithoctona plicata von Olfers, 1816

- Wing membrane setulose 2

2- Wing setulae covering part of cells $3 r$ and $1 m$ sometimes even apex of $2 r$ as well. Anterior mesosternal process narrow, distinctly longer than wide at base. Anterior ocellus situated on or slightly above level of posterior eye-margins. Female abdomen with 3 median tergal plates. Wing not more than $7.5 \mathrm{~mm}$ long (Plate 5, Figs a, b, c, d).

Ornithoctona laticornis (Macquart, 1835)

- Wings partially setulose. Para-anal laterite bearing 3 to 4 long setae. First sternite rectangular and narrow with many rows of spine-like setae of unequal length on the posterior edge. Ocelli area equilateral triangle shaped. Female abdomen with 3 median tergal plates (Plate 6, Figs a, b, c).

Ornithoctona idonea Falcoz, 1929
- Key to species of the genus Ornithoica Rondani, 1878

1- Wing size 3.2-3.5 $\mathrm{mm}$. Wing-setulae covering more than $1 / 2$ of cell $2 m$ and extending to apical $1 / 2$ or more of $2 r$ and to apical margin of $r-m$. Mesoscutum except small areas at its anterolateral corners, as densely setose as prescutum and scutellum. Bare area at base of cell $3 r$ much less than $2 \times$ as that of $1 \mathrm{~m}$.

Ornithoica (Ornithoica) podicipis von Röder, 1892

- Wing size 2.5-2.8 mm. Wing-setulae covering much less than $1 / 2$ of cell $2 m$, generally forming very small patch near its antero-apical corner; cell $2 r$ at most setulose at extreme apex. Cell $r$ - $m$ entirely bare, setulose area in cell $2 \mathrm{~m}$ small confined to antero-apical corner (Plate 5, Figs e, f).

Ornithoica (Ornithoica) hovana Maa, 1966.

\section{ACKNOWLEDGEMENTS}

This work has been funded partly by IRD (Institut I de Recherche pour le Développement). Dr David Willard helped in the collection of the hippoboscid flies reported on herein. Dr Carl W. Dick is thanked for helpful comments and advice on a preliminary version of the manuscript.

\section{REFERENCES}

BAKER J.R. A review of the role played by the Hippoboscidae (Diptera) as vectors of endoparasites. J Parasitol, 1967, 53 (2), 412-418.

BequaErT J.C. Notes on Hippoboscidae 13. A second revision of the Hippoboscinae. Psyche, 1939, 46, 70-90. 
Bequaert J.C. The Hippoboscidae or louse-flies (Diptera) of mammals and birds. Part II. Taxonomy, evolution and revision of American genera and species. Entomol Am, 1954, 34, 1-232.

BRunhes J. Les insectes hématophages de l'archipel des Comores (Diptera, Culicidae, Ceratopogonidae, Simuliidae, Tabanidae, Hippoboscidae et Muscidae Stomoxyinae ; Hemiptera Cimicidae), maladies transmises et méthodes de lutte, in: Faune entomologique de l'archipel des Comores. Mémoires du Muséum National d'Histoire Naturelle, Nouvelle Série, Série A, Zoologie, 1978, 109, 193-246.

Cogan B.H., Hutson A.M. \& Shaffer J.C. Preliminary observations on the affinities and composition of the insect fauna of Aldabra. Phil Trans Roy Soc London B, 1971, 206, 315-325.

DAYNes P. Note sur les helminthoses des animaux domestiques reconnues à Madagascar. Revue d'Élevage et de Médecine Vétérinaire des Pays Tropicaux, 1964, 17, 477-490.

Dick C.W. Checklist of world Hippoboscidae (Diptera: Hippoboscoidea). Department of Zoology, Field Museum of Natural History, Chicago, 2006, 7 p. (http://fm1. fieldmuseum.org/aa/Files/cdick/Hippoboscidae_Checklist_20dec06.pdf).

Dick C.W. High host specificity of obligate ectoparasites. Ecol Entomol, 2007, 32, 446-450.

DitTmar K., Porter M.L., Murray S. \& Whiting M.F. Molecular phylogenetic analysis of nycteribiid and streblid bat flies (Diptera: Brachycera, Calyptratae): implications for host associations and phylogeographic origins. Mol Phylogenet Evol, 2006, 38, 155-170.

Donque G. Contribution géographique à l'étude du climat de Madagascar. Nouvelle Imprimerie des Art Graphiques, Antananarivo, 1975, 478 p.

Falcoz L. Diptères pupipares du Muséum national d'Histoire naturelle de Paris, Hippoboscidae. Encyc Ent, Paris Sér B, Diptera, 1929, 5 (1), 27-54.

Farajollahi A., Crans W.J., Nickerson D., Bryant P., Wolf B., Glaser A. \& Andreadis T.G. Detection of West Nile virus RNA from the louse fly Icosta americana (Diptera: Hippoboscidae). J Am Mosq Control Assoc, 2005, 21 (4), $474-476$.

FERris G.F. \& COLE F.R. A contribution to the knowledge of the Hippoboscidae (Diptera Pupipara). Parasitology, 1922, 14, 178-205

Fuint O.S., McAlpine J.F. \& Ross H.H. A revision of the genus Leptonema Guerin (Trichoptera: Hydropsychidae: Macronematinae). Smith Contr Zool, 1987, 450, 1-193.

Fuchs J., Pons J.M., Goodman S.M., Bretagnolle V., Melo M., Bowie R.C.K., Currie D., Safford R., Virani M.Z, Thomsett S., Hija A., Cruaud C. \& Pasquet E. Tracing the colonization history of the Indian Ocean scops-owls (Strigiformes: Otus) with further insight into the spatiotemporal origin of the Malagasy avifauna. BMC Evolution Biol, 2008, 8, 197.

Goodman S.M. \& Hawkins A.F.A. Les oiseaux, in: Paysages naturels et biodiversité de Madagascar. Goodman S.M. (Ed.), Muséum national d'Histoire naturelle, Paris, 2008, 383-434.
Halos l., Jamal T., Maillard R., Girard B., Guillot J., Chomel B., Vayssier-Taussat M. \& Boulouis H.J. Role of Hippoboscidae flies as potential vectors of Bartonella spp. infecting wild and domestic ruminants. Appl Environ Microbiol, 2004, 70 (10), 6302-6305.

Hutson A.M. New species of the Ornithomya biloba-group and records of other Hippoboscidae (Diptera) from Africa. J Entomol, Ser B, Taxonomy, 1971, 40 (2), 139-148.

Hutson A.M. Diptera: Keds, flat-flies and bat-flies (Hippoboscidae and Nycteribiidae). Handbooks for the identification of British insects. Royal Entomological Society of London, 1984, 10 (7), $84 \mathrm{p}$.

IrWin M.E., Schlinger E.I. \& Thompson F.C. Diptera, true flies, in: The natural history of Madagascar. Goodman S.M. \& Benstead J.P. (Eds), The University Chicago Press, Chicago, 2003, 692-702.

KuCERA J. Incidence and some ecological aspects of avian trypanosomes in Czechoslovakia. Folia Parasitol (Praha), 1983, 30 (3), 209-222.

MaA T.C. Notes on the Hippoboscidae (Diptera). Pacific Insects, 1962, 4 (3), 583-614.

MAA T.C. Genera and species of Hippoboscidae (Diptera): types, synonymy, habitats and natural groupings. Pacific Insects Monograph (Honolulu: Bishop Museum, Honolulu, Hawaii), 1963, 6, 1-186.

MAA T.C. On the genus Lynchia from Africa (Diptera: Hippoboscidae). J Med Entomol, 1964, 1, 87-103.

MAA T.C. The genus Ornithoica Rondani (Diptera: Hippoboscidae). Pacific Insects Monograph (Honolulu: Bishop Museum, Honolulu, Hawaii), 1966, 10, 10-124.

MaA T.C. Synopses of the genera Ornithophila and Ornithoctona with remarks on their habitat diversification (Diptera: Hippoboscidae). Pacific Insects Monograph (Honolulu: Bishop Museum, Honolulu, Hawaii), 1969a, 20, 1-23.

MAA T.C. Revision of Icosta (= Lynchia Auctt.) with erection of a related genus Phthna (Diptera: Hippoboscidae). Pacific Insects Monograph (Honolulu: Bishop Museum, Honolulu, Hawaii), 1969b, 20, 25-203.

MAA T.C. A revised checklist and concise host index of Hippoboscidae (Diptera). Pacific Insects Monograph (Honolulu: Bishop Museum, Honolulu, Hawaii), 1969c, 20, 261-299.

Moat J. \& Smith P. Atlas de la végétation de Madagascar. Kew Publishing, Royal Botanic Gardens, Kew, 2007, 124 p.

Nelson G.S. Dipetalonema dracunculoides (Cobbold, 1870), from the dog in Kenya: with a note on its development in the lousefly, Hippobosca longipennis. J Helminthology, 1963, 37, 235-240.

OYIEKE F.A. \& ReID G. The mechanical transmission of Trypanosoma evansi by Haematobia minuta (Diptera: Muscidae) and Hippobosca camelina (Diptera: Hippoboscidae) from an infected camel to a mouse and the survival of trypanosomes in fly mouthparts and gut (a preliminary record). Folia Veterinaria, 2003, 47, 38-41.

Petersen F.T., Meier R., Kutty S.N. \& Wiegmann B.M. The phylogeny and evolution of host choice in the Hippoboscoidea (Diptera) as reconstructed using four molecular 
markers. Mol Phylogenet Evol, 2007, 45 (1), 111-122.

Quentin R.M. \& Viluiers A. Révision des Macrotomini de la Région malgache [Col. Cerambycidae Prioninae]. Ann Soc Ent Fr, n.s.,1973, 9 (1), 3-68.

Reeves W.K., Nelder M.P., CobB K.D. \& Dasch G.A. Bartonella spp. in deer keds, Lipoptena mazamae (Diptera: Hippoboscidae), from Georgia and South Carolina, USA. J Wildl Dis, 2006, 42 (2), 391-396.

Savage A.F., Robert V., Goodman S.M., Raharimanga V., Raherilalao M.J., Andrianarimisa A., Ariey F. \& Greiner E.C. Blood parasites in birds from Madagascar. $J$ Wildl Dis, 2009, 45 (4), 907-920.

Theodor O. \& Oldroyd H. On a new genus and species of Hippoboscidae (Diptera) and its relationship to Allobosca crassipes Speiser. Proc $R$ Entomol Soc London B Taxonomy, 1965, 34 (7-8), 91-97.

Vaughn S.E. \& McGeE E.M. Association of Allobosca crassipes (Diptera: Hippoboscidae) with the black and white ruffed lemur (Varecia variegata variegata) and Milne-Edwards' sifaka (Propithecus edwardsi) in southeastern Madagascar. Pan-Pacific Entomologist, 2009, 85 (3), 162-166.

Wright P.C., Arrigo-Nelson S.J., Hogg K.L., Bannon B., Morelli T.L., Wyatt J., Harivelo A.L. \& Ratelolahy F. Habitat disturbance and seasonal fluctuations of lemur parasites in the rain forest of Ranomafana National Park, Madagascar, in: Primate parasite ecology. The dynamics and study of host-parasite relationships. Huffman A.H. and Chapman C.C. (Eds), Cambridge University Press, Cambridge, 2009, 311-330.

Received on November $19^{\text {th }}, 2010$

Accepted on February $3^{\text {rd }}, 2011$ 